\title{
STUDIES WITH RADIOACTIVE ENDOTOXIN. III. THE EFFECT OF TOLERANCE ON THE DISTRIBUTION OF RADIOAC- TIVITY AFTER INTRAVENOUS INJECTION OF ESCHERICHIA COLI ENDOTOXIN LABELED WITH CR $\mathrm{CR}^{51}$
}

\author{
By F. J. CAREY, A. I. BRAUDE, 2 AND M. ZALESKY
}

(From the Department of Internal Medicine, Southwestern Medical School, Dallas, Texas)

(Submitted for publication June 3, 1957 ; accepted November 21, 1957)

The repeated injection at frequent intervals of the same dose of a bacterial endotoxin is followed by gradual diminution in the severity of its toxic effects. The state of resistance that develops during the course of such injections has been designated tolerance and is considered to be independent of specific antibody formation, because tolerance for one endotoxin is effective against the toxic action of immunologically distinct endotoxins of other gram-negative bacilli (1-3). The importance of the reticuloendothelial system in the development of tolerance has been explored by Beeson $(4,5)$, who demonstrated that reticuloendothelial "blockade" not only abolished immunity to the Shwartzman reaction, but also tolerance to the febrile response of sublethal doses of bacterial pyrogens.

The heavy localization of radioactivity in the liver of animals injected intravenously with endotoxin labeled with $\mathrm{Cr}^{51}$ has provided evidence that the reticuloendothelial system removes the endotoxin from their circulation (6). In rabbits receiving massive lethal doses of endotoxin intravenously, it was found that the localization of endotoxin in the liver was not enough to prevent the persistent circulation of endotoxin in high concentrations in the plasma for several hours. Thus, 30 to 40 per cent of the total amount of injected radioactivity was present in the circulation for nearly three hours after the injection of 6.0 $\mathrm{mg}$. of radioactive endotoxin in rabbits. Because it seemed likely that these large amounts of circulating endotoxin were responsible for the damag-

1 This work was supported by the Research and Development Division, Office of the Surgeon General, Department of the Army, under contract Number DA-49007-MD-519.

2 Reprint requests should be sent to A. I. Braude, Department of Medicine, University of Pittsburgh Medical School, Pittsburgh, Penna. ing effects of endotoxin, the following study was undertaken to determine whether tolerant animals owed their resistance to an increased removal of lethal doses of endotoxin from the circulation by the liver and other organs rich in reticuloendothelial cells.

\section{METHODS}

Tolerance was measured in rabbits by their resistance to the pyrogenic action of endotoxin and in mice by their resistance to its lethal action. In both species an attempt was made to assess the part played by humoral immunity (circulating antibody) in the development of tolerance and on the distribution of endotoxin. For this reason an effort was made to establish: 1) A tolerant state in which circulating precipitins to endotoxin were absent or low; and 2) a high titer of humoral antibodies in animals who lacked resistance to endotoxin. To accomplish the first objective (tolerance without circulating antibody) animals were given $\mathrm{X}$-irradiation before initiating the injections of endotoxin required for tolerance; to accomplish the second (circulating antibody without tolerance) the injections of endotoxin were discontinued with the expectation that tolerance would lapse while antibody titer persisted at an elevated level. With these purposes in mind, we carried out distribution studies with massive lethal doses of radioactive endotoxin in the following groups of rabbits and mice: 1) normal, 2) tolerant, 3) irradiated tolerant, and 4) lapsed tolerant.

Distribution studies with small doses of endotoxin were also carried out in normal and tolerant animals (Groups 1 and 2) in order to learn whether or not the differences in distribution observed with lethal doses in these two groups would also be found with sublethal doses.

\section{EXPERIMENTAL}

\section{Massive lethal doses of endotoxin}

Albino rabbits weighing 2 to 3.5 kilograms and white Swiss mice weighing approximately 20 grams were obtained from dealers in Dallas and Austin, Texas. They were housed in air-conditioned quarters.

1. Preparation of endotoxin. The endotoxin was prepared from Escherichia coli grown in synthetic media and 
TABLE I

Fever indices before and after a course of endotoxin

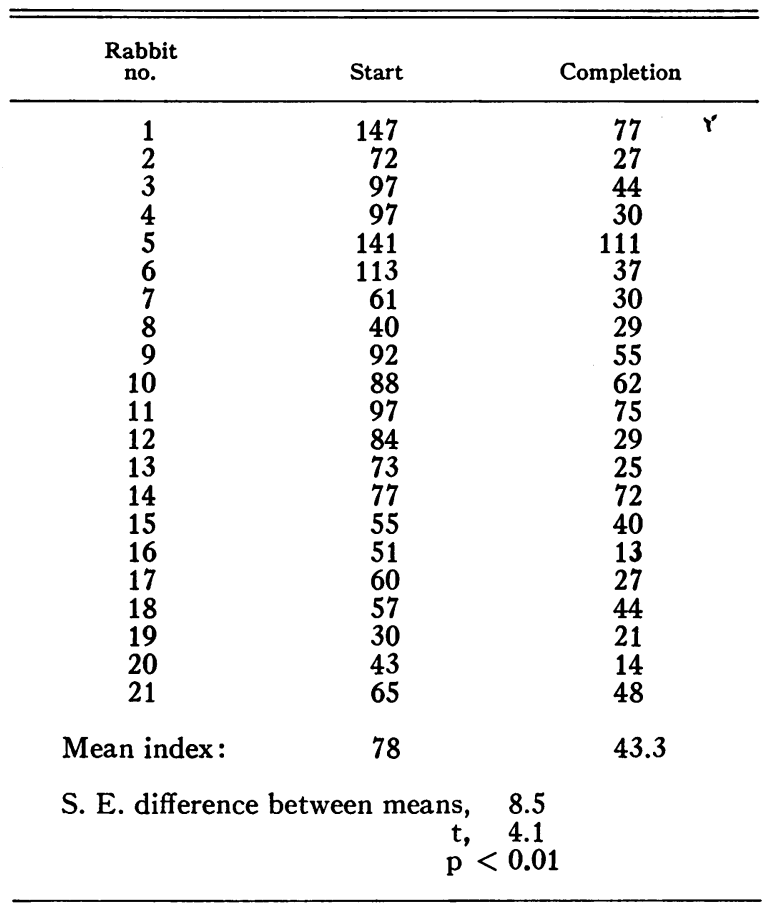

labeled by direct incubation with radioactive chromium (7). The procedure consisted of suspending the endotoxin in a phosphate buffer to give a concentration of $5.0 \mathrm{mg}$. per $\mathrm{ml}$. and incubating at $37^{\circ} \mathrm{C}$. with $\mathrm{Na}_{2} \mathrm{Cr}^{51} \mathrm{O}_{4}$ for 48 hours. Then the suspension of endotoxin was dialyzed against distilled water at 4 to $8^{\circ} \mathrm{C}$. until only insignificant amounts of radioactivity appeared in the dialysis bath. The toxicity $\left(\mathrm{LD}_{50}\right.$ in mice) was not changed upon labeling with $\mathrm{Cr}^{51}$ in these experiments or in those reported earlier (7). The radioactivity of the labeled endotoxin at the time of injection ranged from 200 to 400 counts per second per $\mathrm{mg}$.

2. Injection of radioactive endotoxin. Rabbits were inoculated in the ear vein with $6.0 \mathrm{mg} .{ }^{3} \mathrm{Cr}^{51}$ labeled endotoxin suspended in $1.0 \mathrm{ml}$. of phosphate buffer at the time of the distribution studies. In mice the distribution of two different lethal doses of endotoxin was determined. One group of mice received $0.5 \mathrm{mg}$. of $\mathrm{Cr}^{51}$ labeled endotoxin intracardially and a second group received 1.5 mg. by inoculation into the tail vein. Both doses were given in a volume of $0.25 \mathrm{ml}$. of phosphate buffer.

3. Technique for producing tolerance. In rabbits tolerance was readily established by the repeated injection of the same dose of endotoxin and manifested by a reduction in the amount of fever, weakness and listlessness elicited by that dose.

The schedule for producing tolerance in most rabbits was 11 or 12 injections during 27 days so that one in-

${ }^{3} \mathrm{Six} \mathrm{mg}$. of endotoxin is equal to approximately 10 $\mathrm{LD}_{\mathrm{so}}$ 's. jection was given every second or third day. The first three were given intraperitoneally and the remainder intravenously. The first two doses were $0.025 \mathrm{mg}$. and the remainder $0.05 \mathrm{mg}$.

Temperatures were measured rectally with a thermistor apparatus (E. H. Sargent and Co.). The instantaneous temperature records obtained by this device are more accurate than those which can be measured with the ordinary mercury bulb clinical thermometer. The fever index was calculated by measuring the area under the fever curve plotted over a six hour period. The index is expressed as the number of unit squares contained within a given area on graph paper divided by lines placed 2.5 $\mathrm{mm}$. apart. The fever indices at the start and completion of the schedule of intravenous injections described above for 21 rabbits are shown in Table I.

These values represent a lower and less prolonged febrile response to the intravenous injection of endotoxin in tolerant rabbits. The well known alteration in the shape of the fever curve was also evident after tolerance was established (4). Thus, before tolerance the fever curve had two peaks; after tolerance, the second peak was diminished or failed to appear.

In 10 rabbits (Numbers 1 through 10), injections were discontinued for a period of five weeks. During this time, the titer of precipitins had fallen from 1:16 (average) at the time of the last injection to $1: 4$. Although these animals are referred to as "lapsed-tolerant," they tolerated the lethal injection of endotoxin better than normals as judged by their alertness, their ability to remain standing, their muscle tone when held, and the resistance offered upon removal from their cages. The fever index could not be applied as a measure of tolerance in these animals because another sublethal dose just before the tracer studies would nullify the effect of discontinuing injections.

A group of 12 rabbits was irradiated with $500 \mathrm{r}$ (51 r per minute for 9.8 minutes) two days before beginning

TABLE II

The effect of irradiation on the development of tolerance to injected endotoxin

\begin{tabular}{ccc}
\hline \hline Rabbit & Start & Completion \\
\hline L & 126 & 86 \\
U & 128 & 116 \\
M & 134 & 98 \\
W & 82 & 82 \\
P & 104 & 32 \\
V & 114 & 64 \\
O & 120 & 96 \\
Z & 126 & 96 \\
X & 58 & 48 \\
R & 132 & 82 \\
Mean & 94 & 64 \\
S. E. difference between means, $\quad 6.7$ \\
\multicolumn{2}{c}{ t, $\quad$ p $<.8$} \\
\end{tabular}


TABLE III

The effect of tolerance on the $L D_{60}$ for endotoxin

\begin{tabular}{|c|c|c|c|c|}
\hline \multirow{3}{*}{$\begin{array}{c}\text { Dose } \\
(m g .)\end{array}$} & \multicolumn{4}{|c|}{ Actual mortality rate at $72 \mathrm{hrs}$. after challenge } \\
\hline & \multicolumn{2}{|c|}{ Tolerant } & \multicolumn{2}{|c|}{ Normal } \\
\hline & I.P.* & I.V.† & I.P.* & I.V.† \\
\hline $\begin{array}{l}4.0 \\
2.0 \\
1.0 \\
0.5 \\
0.25 \\
0.125 \\
0.0625 \\
0.0312 \\
0.0156 \\
0.0078 \\
0.0039\end{array}$ & $\begin{array}{l}5 / 5 \ddagger \\
5 / 5 \\
2 / 5 \\
1 / 5 \\
0 / 5\end{array}$ & $\begin{array}{l}4 / 4 \\
5 / 5 \\
9 / 10 \\
4 / 10 \\
3 / 10 \\
0 / 10 \\
0 / 10\end{array}$ & $\begin{array}{l}5 / 5 \\
5 / 5 \\
4 / 5 \\
4 / 5 \\
1 / 5 \\
1 / 5\end{array}$ & $\begin{array}{l}5 / 5 \\
8 / 9 \\
8 / 9 \\
4 / 9 \\
5 / 9 \\
5 / 9 \\
1 / 4 \\
1 / 4\end{array}$ \\
\hline \multicolumn{3}{|c|}{$\begin{array}{l}\text { Tolerant mice challenged intravenously } \\
\text { Tolerant mice challenged intraperitoneally } \\
\text { Normal controls challenged intravenously } \\
\text { Normal controls challenged intraperitoneally }\end{array}$} & \multicolumn{2}{|c|}{$\begin{array}{l}0.25 \mathrm{mg} \text {. } \\
1.00 \mathrm{mg} \text {. } \\
0.025 \mathrm{mg} \text {. } \\
0.097 \mathrm{mg} \text {. }\end{array}$} \\
\hline
\end{tabular}

* I.P., intraperitoneal challenge.

$\dagger$ I.V., intravenous challenge.

$\ddagger$ The numerator represents deaths and the denominator total number of mice inoculated with a given dose.

the series of injections leading to tolerance. The irradiation was given with $250 \mathrm{KV}: 15 \mathrm{ma} 1 / 2 \mathrm{Cu} 1 \mathrm{Al}$ filter at a distance of $78 \mathrm{~cm}$. to the center of the carrier in which the rabbits were contained. At four and nine-tenths minutes, the positions of the two rabbits in each container were reversed. The fever indices at the start and completion of intravenous injections of endotoxin are shown in Table II.

4. Technique for producing tolerance in mice. One sublethal dose of endotoxin was injected intraperitoneally every other day for a total of six doses. The schedule consisted of $0.005 \mathrm{mg}$. of endotoxin for the first dose, $0.01 \mathrm{mg}$. for the second, and $0.02 \mathrm{mg}$. of endotoxin for the remaining four doses. This technique always produced tolerance which could be demonstrated by the high doses of endotoxin tolerated upon intravenous as well as intraperitoneal challenge. The results shown in Table III, for example, were obtained with this schedule of injections when the mice were challenged three days after the last injection. The mice weighed 20 grams and the intravenous injections were made in the tail vein. The $L_{50}$ 's, calculated by the method of Reed and Muench (8), after 72 hours are also shown.

These results disclose that this schedule increased the tolerance about 10 times over normal whether tolerance was measured intravenously or intraperitoneally. On the day of all tracer experiments with radioactive endotoxin the $\mathrm{LD}_{50}$ was calculated in animals which had received simultaneously the same schedule of injections as the test animals.

Animals with lapsed tolerance were those in which the $\mathrm{LD}_{\mathrm{s0}}$ had been permitted to fall approximately to normal through lapse of time after the last injections of endotoxin. The period required for tolerance to lapse was variable. In some animals tolerance persisted for two to three weeks with little change. In others, tolerance would disappear in this time. Enough extra mice were therefore incorporated into each group to permit periodic determinations of the degree of tolerance.

5. Sacrifice of animals and preparation of tissues. All rabbits and mice were sacrificed at the specified time intervals by exsanguination through the heart. Saline was given intravenously to rabbits during the exsanguination procedure so that the animals remained alive long enough to permit removal of maximum amounts of blood.

The tissues of all sacrificed animals were weighed and then soaked in tap water at $4^{\circ} \mathrm{C}$. until the washings contained little or no hemoglobin in a 24 hour period. This procedure was necessary to insure that the radioactivity in an organ was not that of the blood contained within it. Admittedly, endotoxin could be lost from the tissues but it is unlikely that a large proportion would disappear in view of the finding that the total radioactivity in the combined washings did not exceed by more than 5 per cent of the total injected that amount calculated to be present in the blood which had been washed out. The amount of radioactivity in the blood washed out of the tissues was approximately equal to the difference between total circulating radioactivity and radioactivity in the sample removed by cardiac puncture.

The tissues of rabbits were then dried in an oven at $100^{\circ} \mathrm{C}$. and digested with concentrated nitric acid. The tissues of mice were not digested, with the exception of

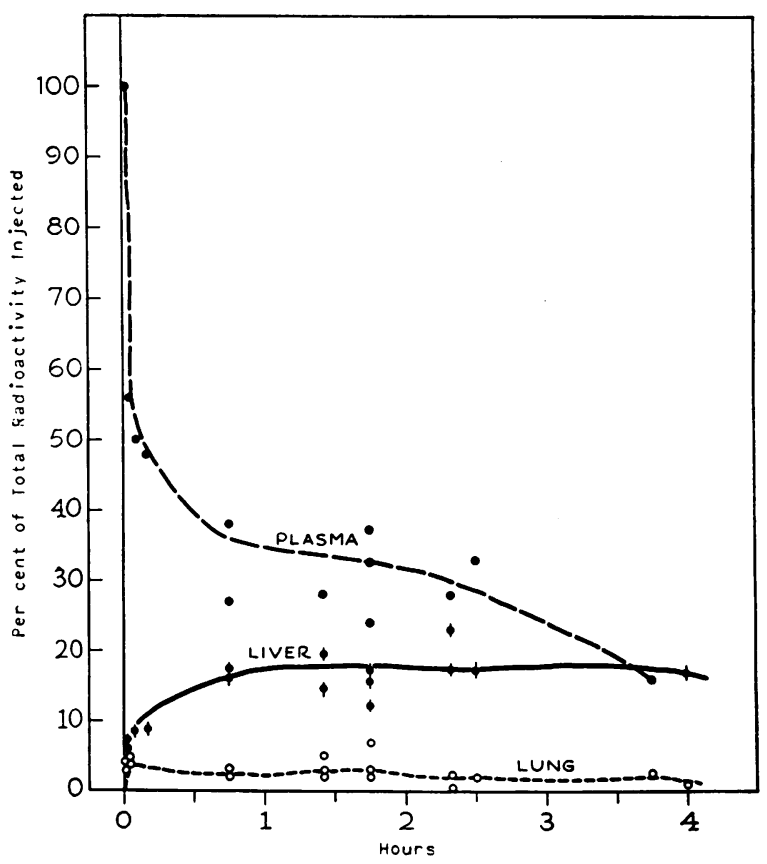

Fig. 1. Distribution of Radioactivity in Normal RABBITS

Each normal rabbit received an injection of a massive lethal dose $(6.0 \mathrm{mg}$.) of radioactive endotoxin. 


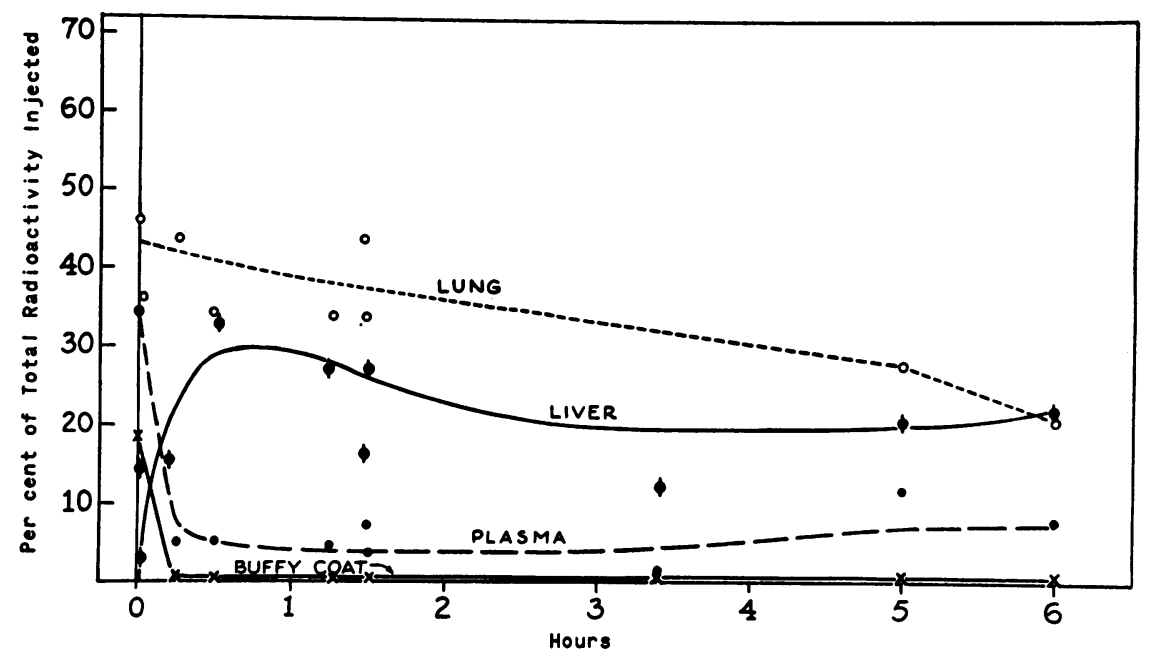

Fig. 2. Distribution of Radioactivity in Tolerant Rabbits

Each tolerant rabbit received an injection of a massive dose $(6.0 \mathrm{mg}$.) of endotoxin.

muscle and intestine. The radioactivity of the tissues and injected chromium was determined as previously described in the scintillation counter after counting for 10 minutes (6). Total amount of circulating radioactivity in whole blood, plasma, buffy coat and red cells of each animal was calculated from the activity of the samples examined on the basis of an estimated total blood volume of $5 \mathrm{ml}$. per 100 grams of body weight. This figure for blood volume is based on our measurement in rabbits (6), as well as those of Courtice and Gunton (9), Kaplan (10), and Armin, Grant, Pels, and Reeve (11). Our attempts to measure the blood volume in mice with $\mathrm{Cr}^{61}$

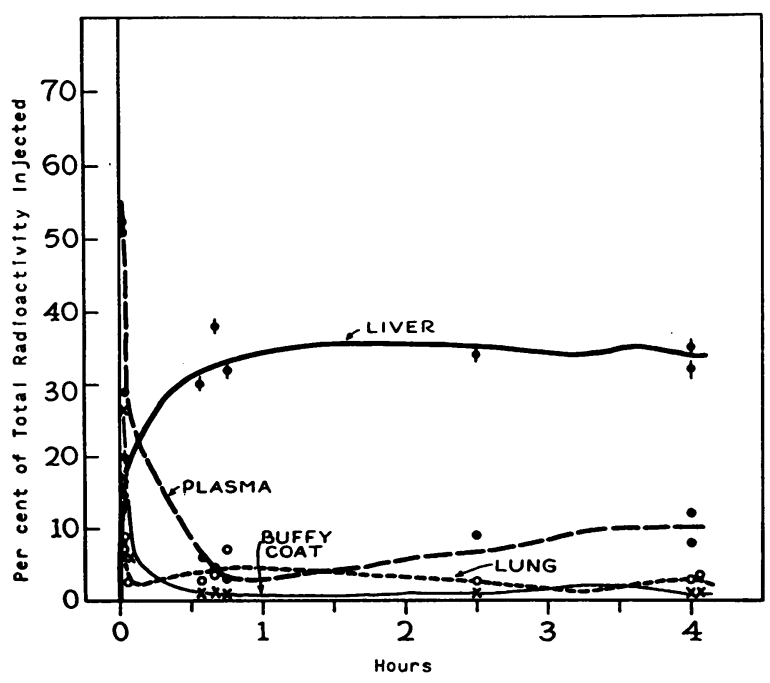

Fig. 3. Distribution of Radioactivity in Tolerant Rabbits With Low Precipitin Titers

The average titer was $1: 1$. Each tolerant rabbit received an injection of a massive dose $(6.0 \mathrm{mg}$.) of endotoxin. labeled red cells were unsuccessful and no reports were found in the literature. In rats, careful studies with $F^{\infty 0}$ and $\mathrm{P}^{22}$ labeled red cells indicate that the blood volume is 4.59 plus or minus $0.57 \mathrm{ml}$. per 100 gram body weight (12).

6. Precipitin tests. Blood was collected from all rabbits by cardiac puncture on the day before the experiment and the serum used for determining the titer of antibody. One-half $\mathrm{ml}$. of each serial dilution of serum was placed in a tube measuring 75 by $12 \mathrm{~mm}$. and mixed with an equal volume of saline containing $1.0 \mathrm{mg}$. of endotoxin. The mixture was incubated at $37^{\circ} \mathrm{C}$. for one to two hours and then refrigerated overnight. After centrifugation at 2,000 rpm for five minutes the tubes were examined macroscopically and the titer recorded as the highest dilution of serum accompanied by the formation of a gross precipitate.

For precipitin tests on the sera of mice, blood was collected on the day of the experiment by cardiac puncture of 6 to 12 mice in each group. These mice, which had received the same preparatory manipulations as the others in each group, were not subjected to tracer studies. Precipitin tests were performed on the sera of individual mice in capillary tubes measuring 1.5 to $2.0 \mathrm{~mm}$. in diameter. Equal amounts of serum diluted serially and of a suspension of endotoxin (1 mg. per $\mathrm{ml}$. of saline) were drawn into the tube and incubated at $37^{\circ} \mathrm{C}$. for 48 hours and the zone of precipitate at the interface measured in millimeters.

\section{RESULTS}

\section{Tracer studies in rabbits (see Figures 1 through} 5)

\section{A. Normals}

Endotoxin was carried in the plasma but not red cells immediately after intravenous injection. 


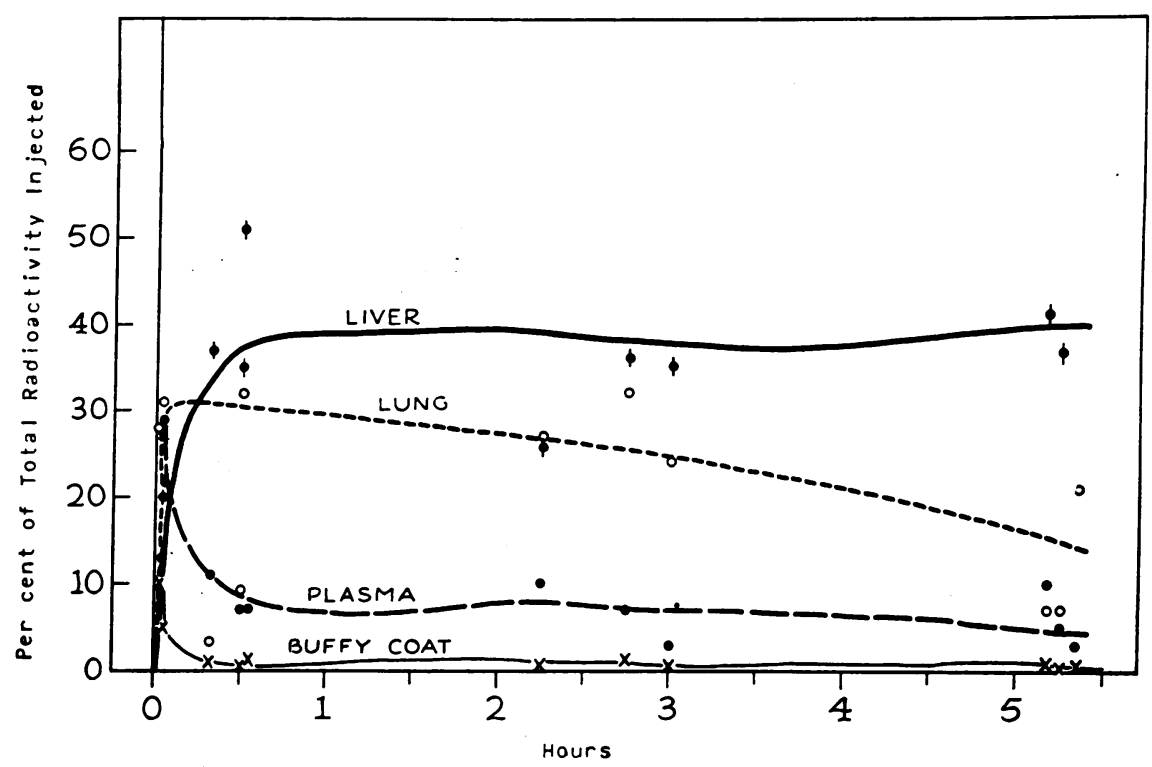

Fig. 4. Distribution of Radionctivity in Irradiated Tolerant Rabbits With High Precipitin Titers

The average titer was 1:15. Each irradiated-tolerant rabbit received an injection of a massive dose ( $6.0 \mathrm{mg}$.) of radioactive endotoxin.

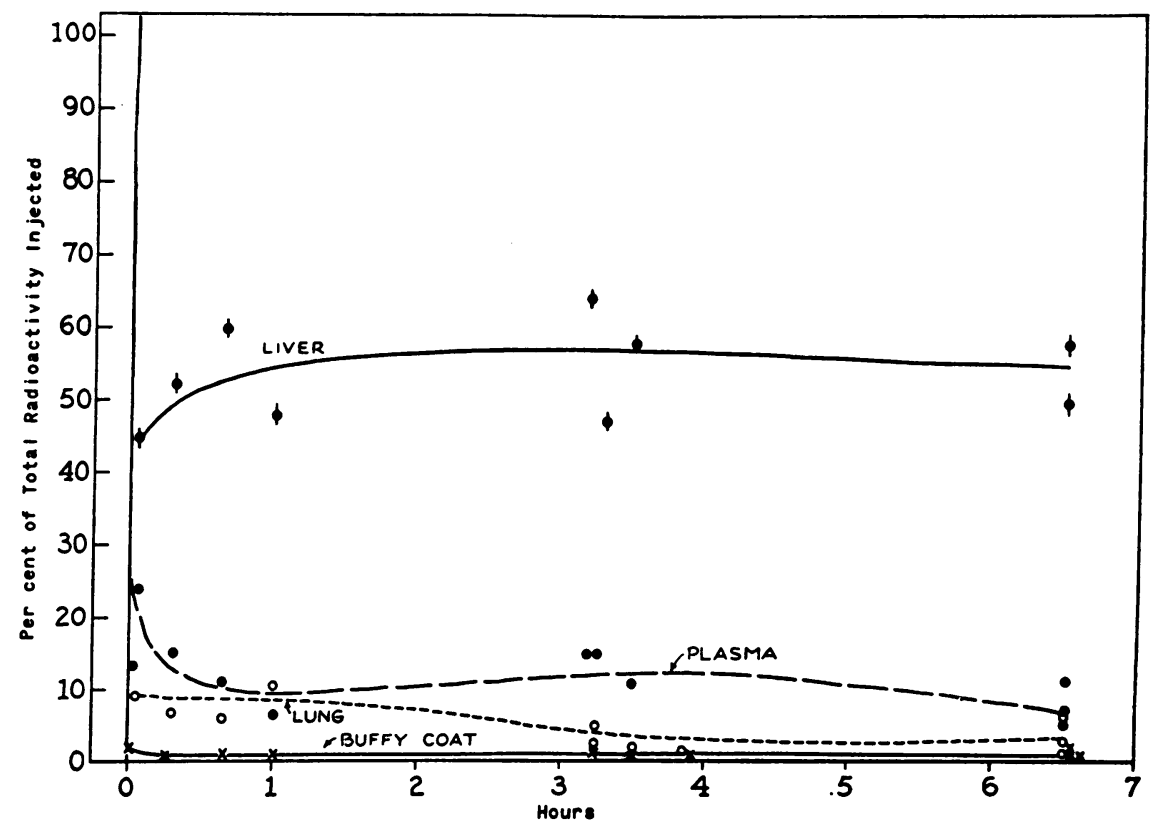

Fig. 5. Distribution of Radioactivity in Rabbits Whose Tolerance Was Allowed to LAPSE

Each lapsed-tolerant rabbit received an injection of a massive dose (6.0 mg.) of radioactive endotoxin. Serum precipitin titers at height of tolerance, 1:16; after lapse of tolerance, $1: 4$. 
Within an hour the plasma concentrations of endotoxin fell to 25 to 40 per cent of the total injected and remained in that range during the first four hours. As it left the plasma, the largest percentage of endotoxin went to the liver and a high concentration appeared on the buffy coat. Only a small per cent of the total went to the lung or spleen (Figure 1).

\section{B. Tolerant}

In less than 20 minutes, the plasma concentration of endotoxin fell below 10 per cent and never rose. The great majority of the endotoxin passed immediately into the lung and remained in that organ in concentrations above 30 per cent during most of the period of observation. Endotoxin accumulated in the liver less rapidly and reached concentrations of 20 to 30 per cent. An enormous amount of endotoxin (18.3 per cent) was found in the buffy coat immediately after injection but the concentration there fell rapidly afterwards (Figure 2). As a result of an accident, precipitin titers were not obtained on the sera of these animals.

In order to repeat the experiment in tolerant rabbits with known antibody titer, a group of 9 rabbits was given 12 intravenous injections of endotoxin during 32 days in doses of $0.001 \mathrm{mg}$. except on Days 3 and 5 when the dose was $0.0005 \mathrm{mg}$. and on the twenty-first day when it was $0.100 \mathrm{mg}$. Tolerance was evident by the fever indices of all animals upon completion of injections which had fallen as follows:

$\begin{array}{lrrrr}\text { Rabbit no. } & \text { A } & \text { B } & \text { C } & \text { D } \\ \text { Start } & 138 & 130 & 88 & 104 \\ \text { Completion } & 58 & 40 & 28 & 30\end{array}$

In these rabbits precipitins were present in such low titer that they could be detected only in the undiluted sera. The distribution of endotoxin differs from that in the preceding group of tolerant animals in that only small amounts appear in the lung. The disappearance from the plasma is very rapid, however, with concentration falling below 10 per cent in 30 minutes. The massive uptake by buffy coat in concentrations reaching 27 per cent during the first few minutes is also found in these animals (Figure 3 ).

\section{Irradiated tolerant}

Within 30 minutes the level of circulating endotoxin fell permanently to less than 10 per cent of the total injected and appeared almost instantly in the lung in concentrations of approximately 30 per cent. Pulmonary radioactivity persisted in concentrations above 20 per cent for five hours. Hepatic uptake of endotoxin rose above 30 per cent within 30 minutes and remained at that level throughout the experiment. Despite the earlier use of X-irradiation, these rabbits developed high serum precipitin titers. Their average was $1: 15$, and they ranged from $1: 8$ to $1: 32$ (Figure 4). While this experiment failed in its primary purpose to arrest antibody formation by irradiation, the results are presented because they demonstrate in rabbits the influence of humoral antibody on pulmonary localization of endotoxin and thus amplify the result obtained in nonirradiated tolerant rabbits whose precipitin titer could not be measured.

\section{Lapsed tolerant}

Endotoxin was removed from the plasma almost as rapidly as in tolerant animals (Figure 5). It dropped to circulating levels in the average range of 11 per cent in 45 minutes and remained at low levels subsequently. The endotoxin was removed mainly by the liver and almost instantly appeared there in concentrations of 45 to 60 per cent. The uptake in the lung was only slightly increased above normal. The precipitin titers in these ani-

\begin{tabular}{|c|c|c|c|c|}
\hline $\begin{array}{c}\mathrm{E} \\
104\end{array}$ & $\begin{array}{l}\mathrm{F} \\
50\end{array}$ & $\begin{array}{l}\mathrm{H} \\
56\end{array}$ & $\begin{array}{c}I \\
76\end{array}$ & $\begin{array}{ll}\mathrm{J} & \mathrm{L} \\
102 & 40\end{array}$ \\
\hline 40 & 40 & 28 & 36 & 38 \\
\hline
\end{tabular}

mals ranged from $1: 2$ to $1: 8$ and the average was $1: 4$. At the time of the last injection of endotoxin given to induce tolerance, the average titer had been $1: 16$ and ranged from $1: 8$ to $1: 64$.

\section{Tracer studies in mice}

\section{A. Normals}

The results are given in Figures 6 and 7. The rate of removal of a lethal dose from whole blood was the same for $0.5 \mathrm{mg}$. and $1.5 \mathrm{mg}$. of endotoxin. 


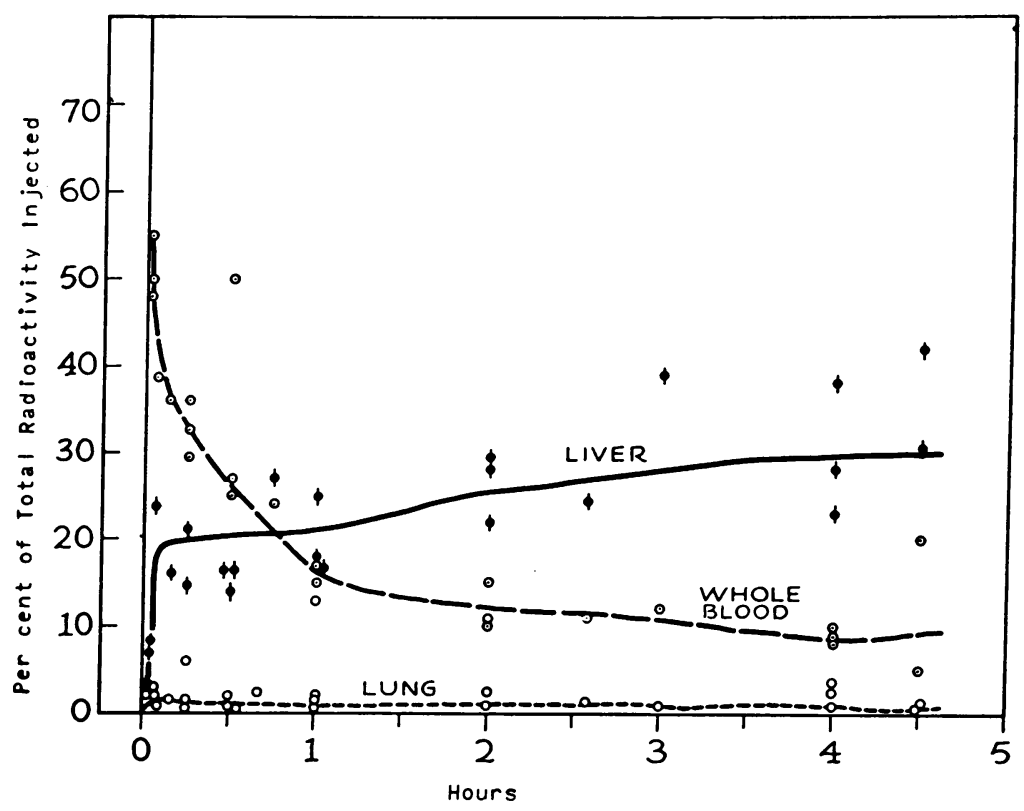

Fig. 6. Distribution of Radioactivity in Normal Mice Receiving 1.5 MG. ENDOTOXIN

The circulating concentration remained above 20 per cent of the total injected during the first hour and most of it passed into the liver. The amount localizing in the lung seldom exceeded 2 per cent of the total radioactivity.

\section{B. Tolerant mice}

Tracer studies were performed in three groups of tolerant mice. In one group the precipitins in the serum were high (average, $1: 32$ ) ; in the second group low (1:2 or less); and in the third

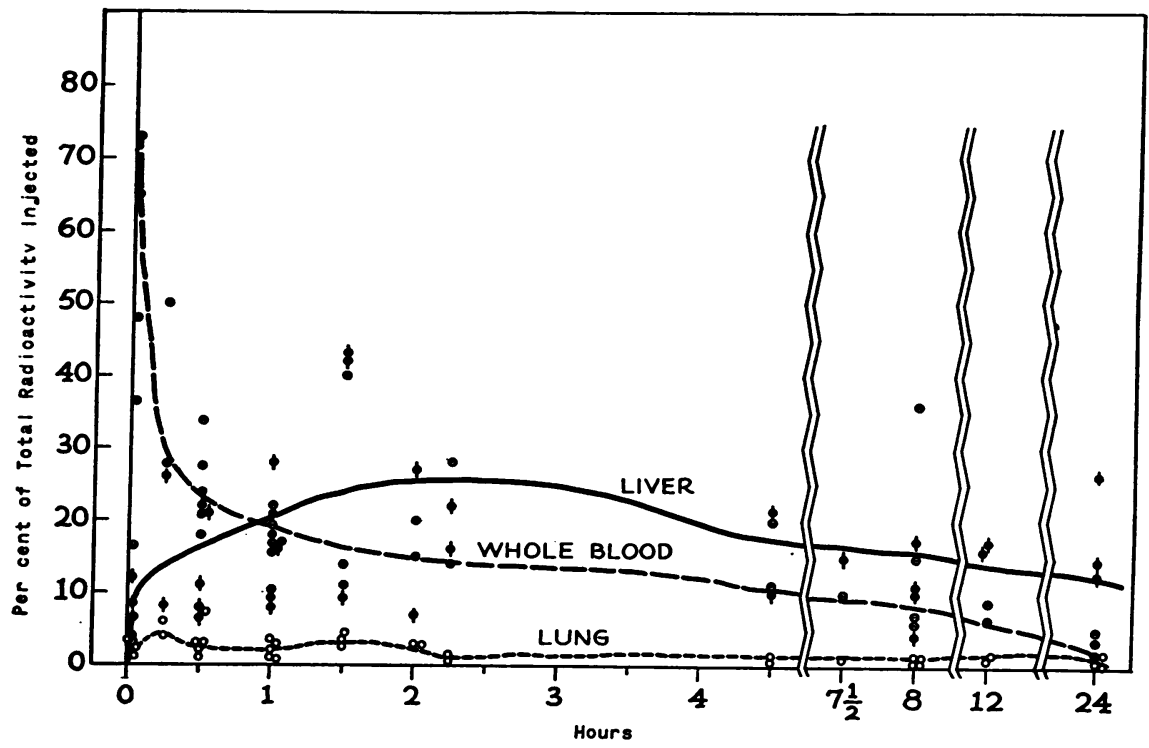

Fig. 7. Distribution of Radioactivity in Normal Mice Receiving Injection of 0.5 Mg. Endotoxin 


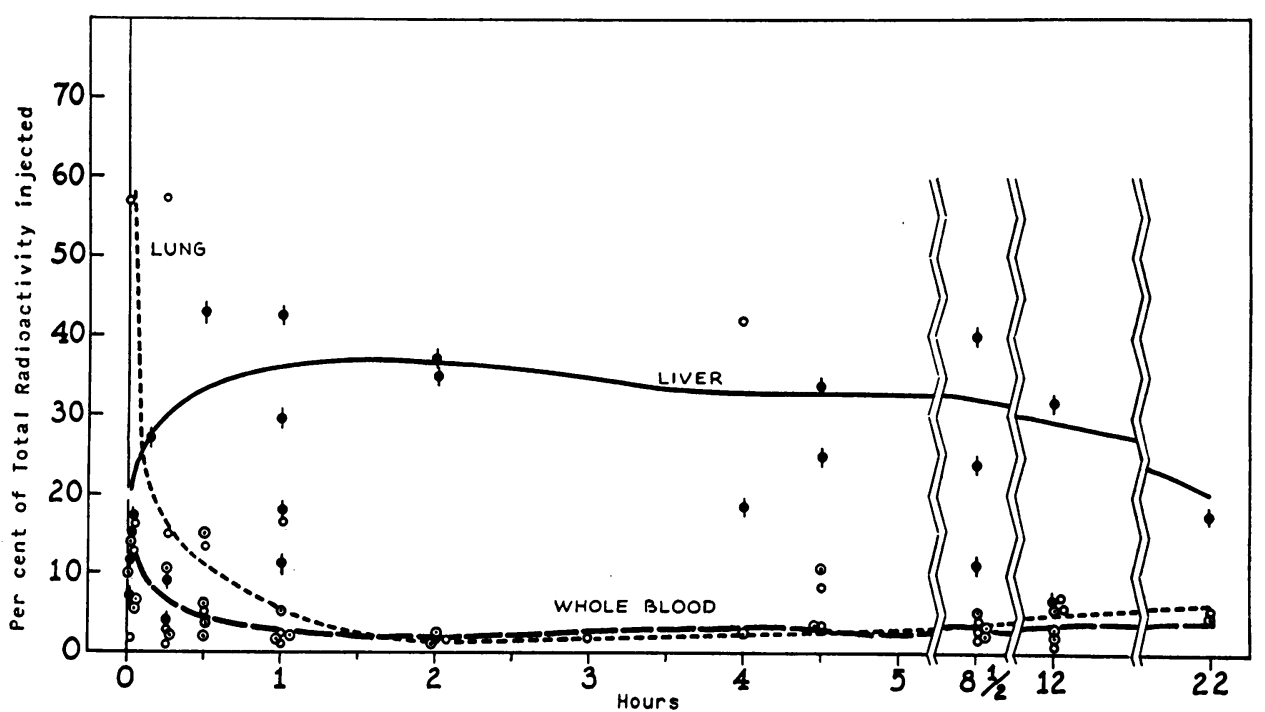

Fig. 8. Distribution of Radioactivity in Tolerant Mice With High Titers of Serum Precipitins Receiving Massive Doses of Endotoxin

the precipitins were high (average, $1: 32$ ), but the animals received colloidal iron intravenously ( 2 mg. saccharated iron oxide) 12 hours before the tracer studies. The purpose of the colloidal iron was to block the reticuloendothelial system (13) and abolish tolerance; this was not successful.

1) Tolerant mice with high titers of precipitins $\left(L D_{50}, 2.22 \mathrm{mg}\right.$.; normals, $0.055 \mathrm{mg}$.). The composite results of two experiments are given in Figure 8. The removal curves resembled those of tolerant rabbits in the following respects: 1) im- mediate fall of blood level to less than 5 per cent; and 2) high initial uptake in lung in the majority of mice. Unlike tolerant rabbits, however, the endotoxin left the lung after an hour so that less than 10 per cent of that injected was found there beyond that time.

2) Tolerant mice with low titers of precipitins $\left(L D_{50}, 0.25 \mathrm{mg}\right.$; normals, 0.044). These mice failed to develop a high titer of precipitins even though given the same schedule of injection of endotoxin as the preceding group. The results

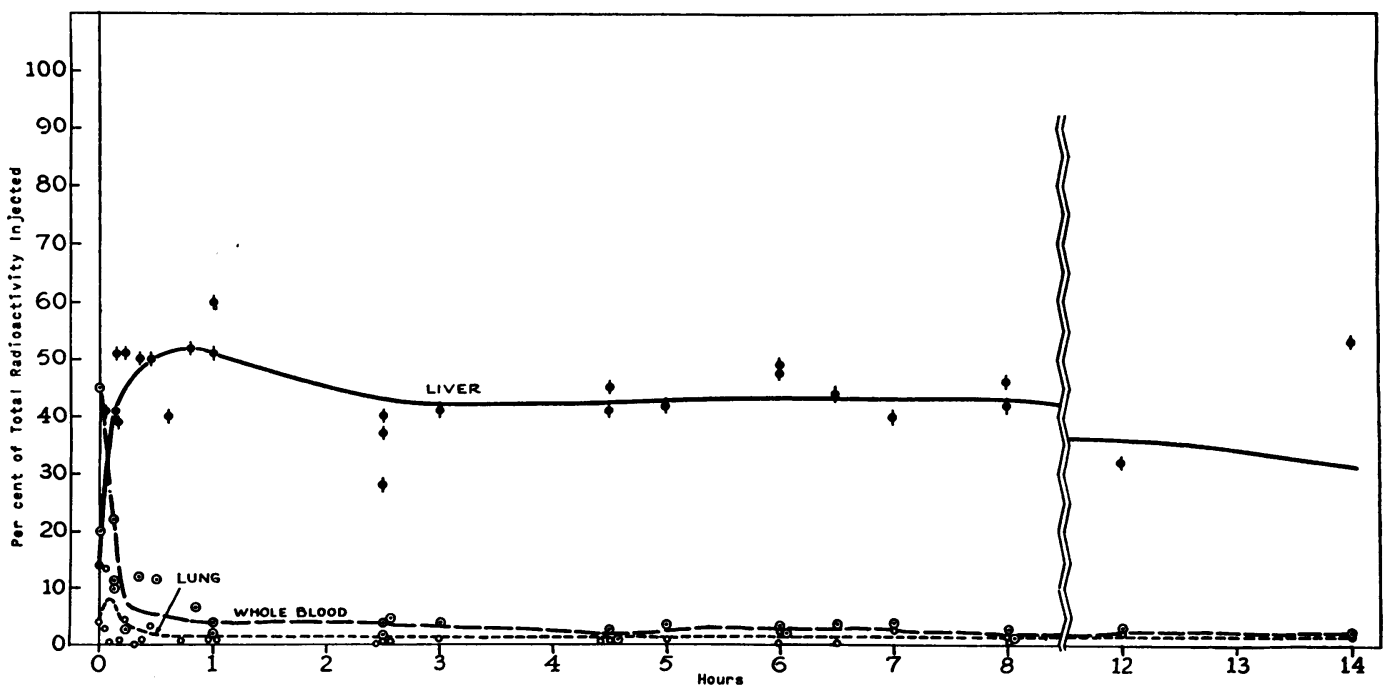

Fig. 9. Distribution of Radioactivity in Tolerant Mice With Low Titers of Serum Precipitins (1:2) Receiving $1.5 \mathrm{Mg}$. Endotoxin 


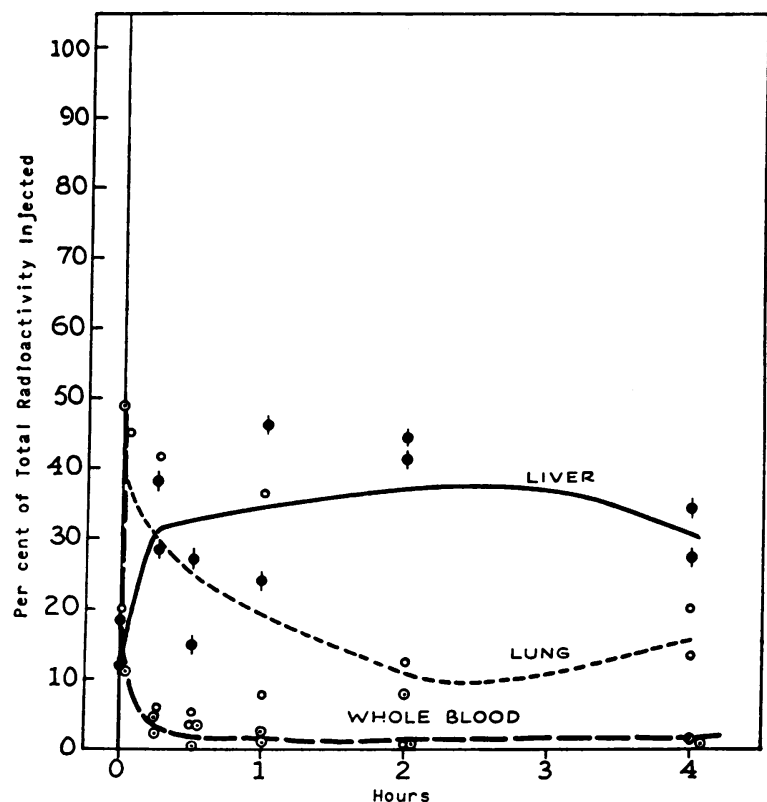

Fig. 10. Effect of Colloidal Iron on Distribution of Radioactive Endotoxin in Twelve Tolerant MICE

Each had received intravenously $2 \mathrm{mg}$. of saccharated iron oxide 12 hours before intravenous injection of 1.5 mg. radioactive endotoxin.

are given in Figure 9. The distribution differs from that seen in tolerant mice with high titers in the following respects: 1) initial uptake in lung is low ; 2) blood levels fall a little more slowly and

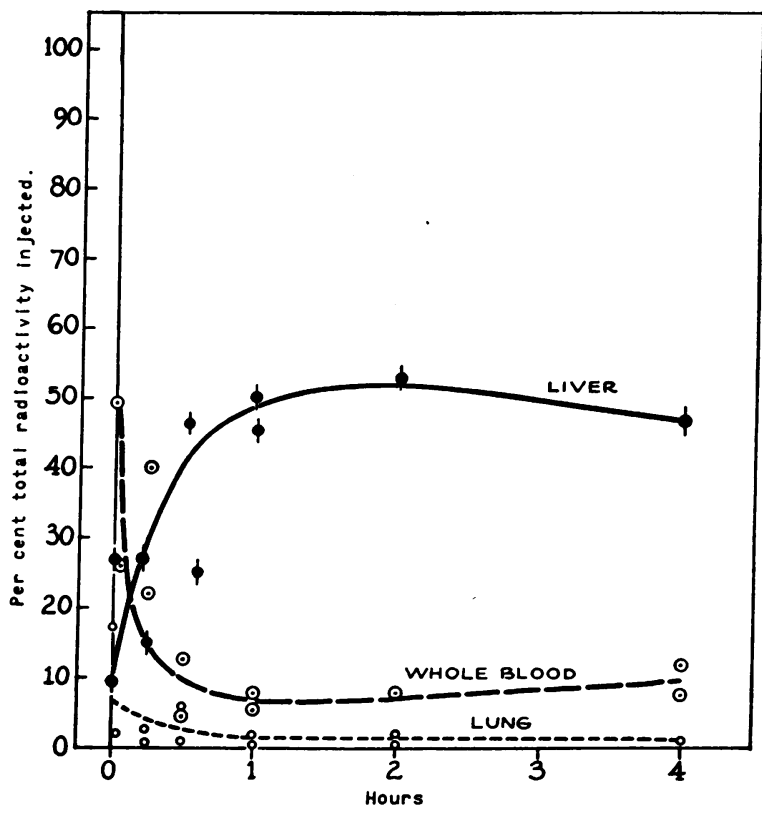

Fig. 11. Distribution of Radioactivity in IrRadiatedTolerant Mice Receiving 1.5 Mg. Endotoxin

Serum precipitin titers were less than $1: 2$. Titer in nonirradiated tolerant was $1: 32$.

not quite as low as in tolerant animals with high titers; and 3) uptake by the liver is faster and greater than in tolerant mice with high precipitin titers.

3) Tolerant mice with high titers of precipitins pretreated with intravenous colloidal iron.

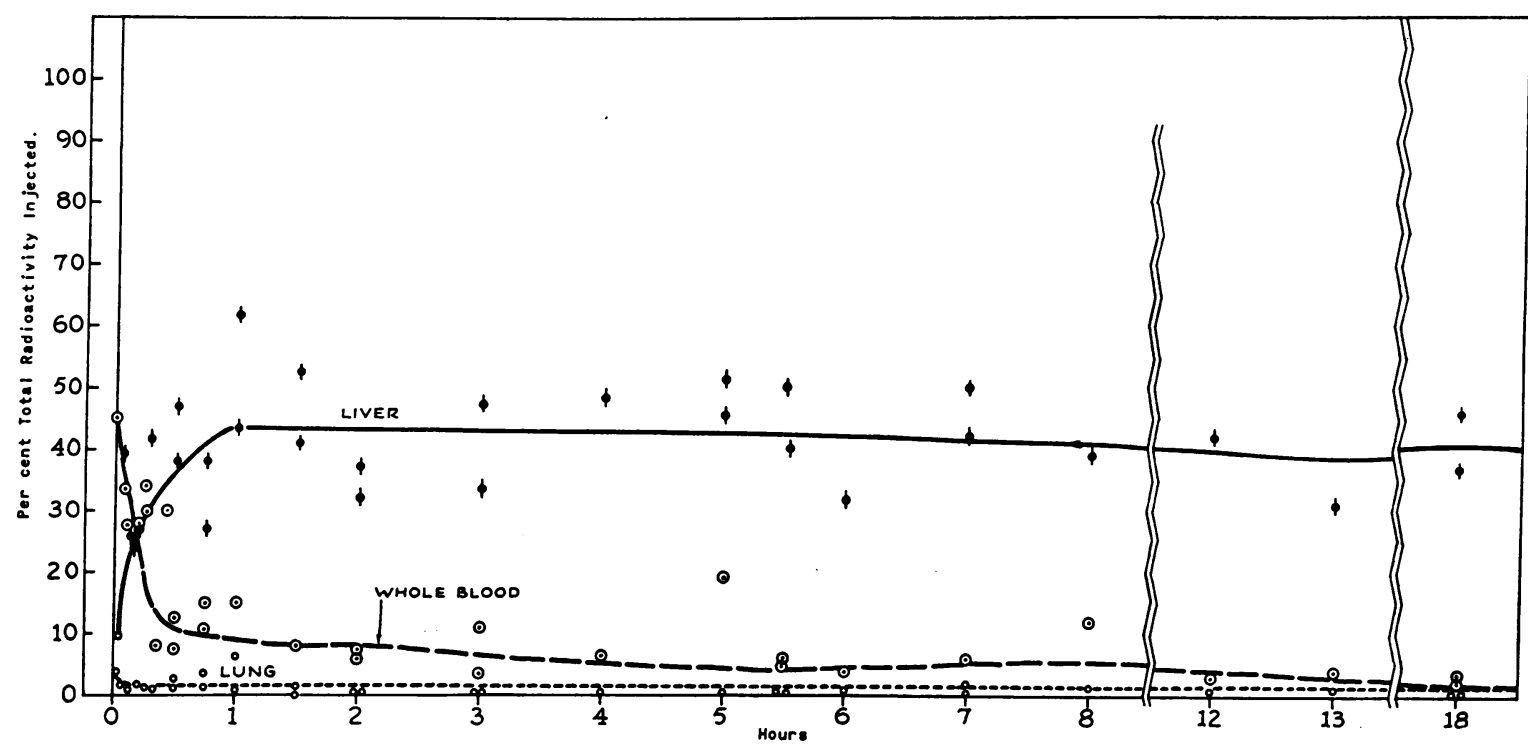

Fig. 12. Distribution of Radioactivity in Irradiated-Tolerant Mice Receiving 1.5 Mg. Endotoxin Serum precipitins were absent in irradiated-tolerant animals and only $1: 2$ in the nonirradiated-tolerant. 
The colloidal iron did not interfere with removal of endotoxin from the circulation (Figure 10) and did not reduce tolerance. In fact, tolerance was enhanced as shown by the following $\mathrm{LD}_{50}$ 's at the time of the distribution studies : 1 ) normals, 0.02 ; 2 ) tolerant, $1.22 ; 3$ ) tolerant mice receiving colloidal iron, 3.5 .

\section{Irradiated tolerant mice}

When each of the two groups of tolerant mice in the preceding experiment (one with high precipitin titers, and one with low titers) was made tolerant, a parallel group of irradiated mice was injected with endotoxin simultaneously and with identical dosages. The irradiation had been given in the form of $350 \mathrm{r}(220 \mathrm{KV}: 17 \mathrm{ma} 1 / 2 \mathrm{Cu} 1 \mathrm{~A} 1$ filter at $50 \mathrm{~cm}$.) at the rate of $59 \mathrm{r}$ per mm. Injections were started in one group 24 hours after irradiation (Figure 11) and 3 hours after irradiation in the second group (Figure 12). Both groups of animals developed tolerance but the precipitin titers were very low (less than $1: 2$ ). In the first group, $\mathrm{LD}_{50}$ equals $0.82 \mathrm{mg}$; normals, 0.2 $\mathrm{mg}$.; nonirradiated tolerant, $1.2 \mathrm{mg}$. In the sec- ond group, $\mathrm{LD}_{50}$ equals $0.156 \mathrm{mg}$., normals, 0.086 mg.

1) The rate of removal from the blood was slower than in the corresponding tolerant mice, but faster and greater than the normal controls. Within one and one-half hours the level fell to 8 per cent (half that of normals).

2) There was almost no uptake by the lung.

3) Most of the endotoxin passed into the liver and greatly exceeded the uptake of nontolerant livers. It is especially noteworthy that the initial rapid disappearance from plasma into the lung was abolished in the group which failed to develop the high precipitin titer observed in its nonirradiated counterpart.

\section{Lapsed tolerant}

Two groups were studied:

1) Tolerance lapsed completely but antibodies persisted elevated to $1: 16$ to $1: 32$ (Figure 13). $\mathrm{LD}_{50}$ at height of tolerance was $2.22 \mathrm{mg}$; ; normals at that time, $0.55 . \mathrm{LD}_{50}$ at time of distribution study was 0.089 ; normals, 0.071 .

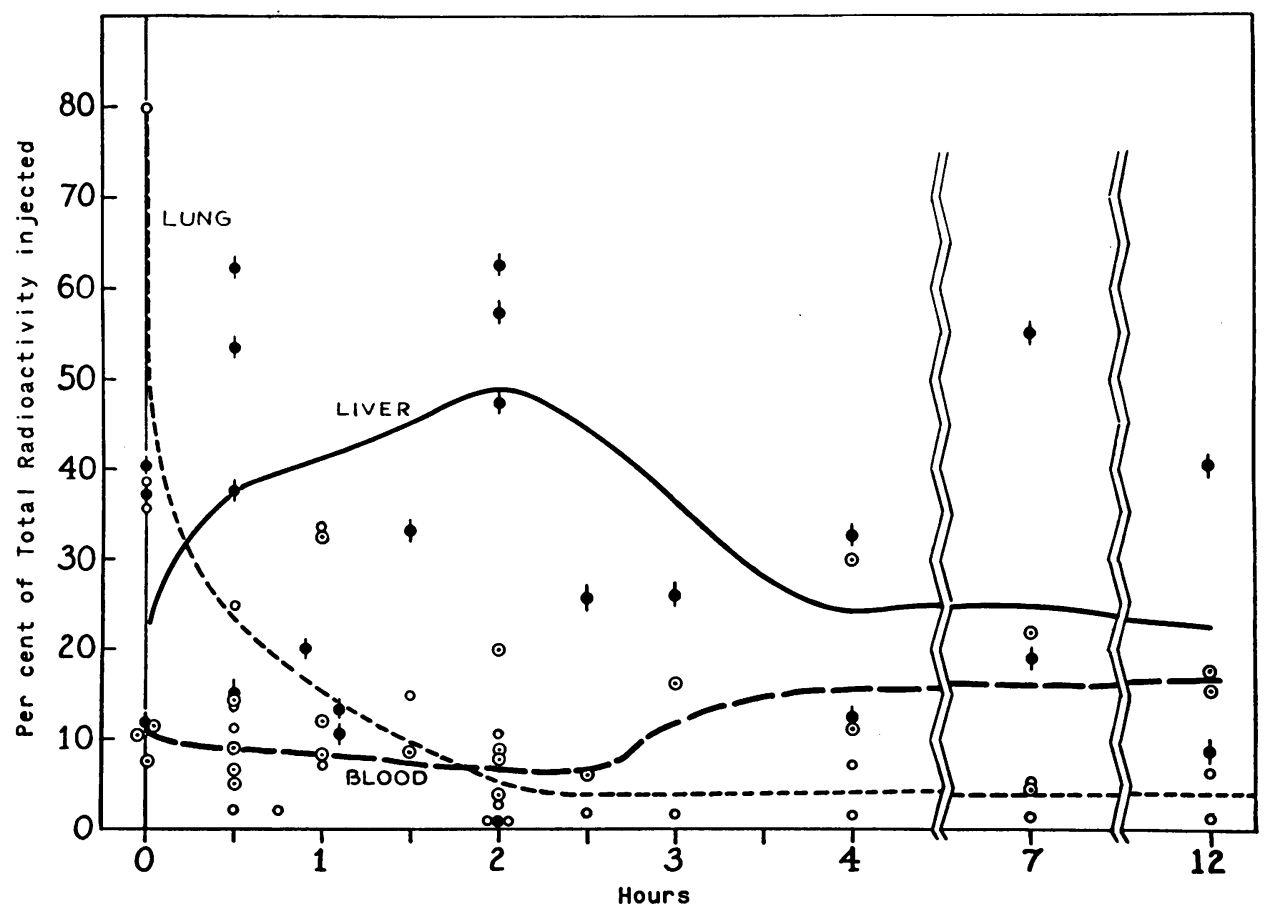

Fig. 13. Distribution of Radioactivity in Mice Whose Tolerance Had Lapsed

Each mouse received $0.5 \mathrm{mg}$. radioactive endotoxin intracardially. Serum precipitin titers equal $1: 16$ and $1: 32$. 


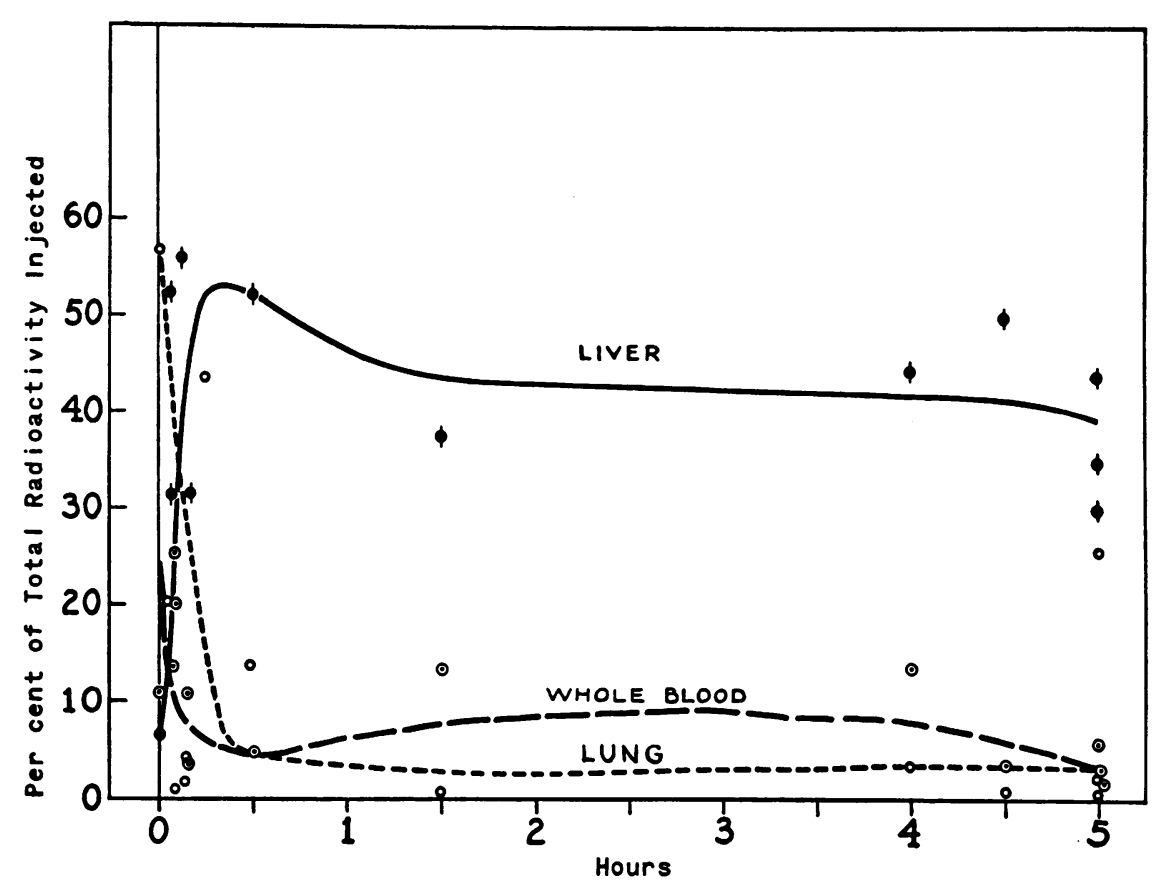

Fig. 14. Distribution of Radioactivity in Mice Whose Tolerance Had Only Partially LAPSED

Each animal received $1.5 \mathrm{mg}$. radioactive endotoxin intravenously. Serum precipitin titers equal $1: 8$ plus.

These animals showed an initial rapid removal by the lung, and the blood level then fell almost instantly to an average level of 10.8 per cent during the first two and one-half hours. Endotoxin also passed to the liver immediately and reached concentrations close to 50 per cent. But neither the lung nor the liver held the endotoxin, and it reappeared in the circulation. The mean concentration in the blood after three hours was 17 per cent, in contrast to the tolerant mice from the same group with high titers of precipitins (Figure 8) whose circulating level in the blood remained at a mean of 4 per cent (S.E. of tolerant after three hours, 0.882 ; S.E. lapsed tolerant after three hours, 1.72. Standard error of difference, $3.02 ; \mathrm{t}, 4.3 ; \mathrm{p}<0.01)$.

2) Tolerance lapsed only partially and antibody titer remained elevated. $\mathrm{LD}_{50}$ at height of tolerance was $1.22 \mathrm{mg}$; normal, 0.2. $\mathrm{LD}_{50}$ at time of distribution study was 0.263 ; normal, 0.122 (Figure 14).

The mice that retained partial tolerance did not relinquish their initial high concentrations of endotoxin in the liver, so that circulating blood levels remained at a mean of 5.2 per cent after three hours.

\section{EXPERIMENTAL}

Small sublethal doses of endotoxin

The materials and methods were the same as those described above, except as noted below.

Rabbits were divided into three groups. One group was made tolerant to the pyrogenic action by injecting

TABLE IV

Fever indices before and after development of tolerance in rabbits receiving small doses of endotoxin

\begin{tabular}{|c|c|c|c|c|c|}
\hline \multirow[b]{2}{*}{ Rabbit } & \multicolumn{2}{|c|}{ Schedule I } & \multirow[b]{2}{*}{ Rabbit } & \multicolumn{2}{|c|}{ Schedule II } \\
\hline & Before & After & & Before & After \\
\hline $\begin{array}{l}\text { A } 6 \\
\text { O 6 } \\
\text { H } 6 \\
\text { G } 6 \\
\text { C } 6 \\
\text { B 6 } \\
\text { M6 } \\
\text { D } 6 \\
\text { E }\end{array}$ & $\begin{array}{r}80 \\
112 \\
100 \\
114 \\
90 \\
104 \\
112 \\
142 \\
110\end{array}$ & $\begin{array}{r}20 \\
48 \\
78 \\
102 \\
68 \\
78 \\
60 \\
92 \\
72\end{array}$ & $\begin{array}{l}\text { A 13 } \\
\text { B 13 } \\
\text { C 13 } \\
\text { D 13 } \\
\text { E 13 } \\
\text { H 13 } \\
\text { K 13 } \\
\text { L } 13 \\
\text { M 13 } \\
\text { P 13 }\end{array}$ & $\begin{array}{r}106 \\
126 \\
114 \\
96 \\
84 \\
66 \\
124 \\
74 \\
126 \\
90\end{array}$ & $\begin{array}{l}56 \\
46 \\
38 \\
16 \\
60 \\
36 \\
74 \\
50 \\
34 \\
36\end{array}$ \\
\hline Mean index & x 110.6 & 68.6 & & 100.6 & 44.6 \\
\hline
\end{tabular}


TABLE V

Serum precipitin titer against endotoxin in tolerant mice *

\begin{tabular}{|c|c|c|c|c|c|c|c|c|}
\hline $\begin{array}{c}\text { Mouse } \\
\text { no. }\end{array}$ & Undil. & $1: 2$ & $1: 4$ & $1: 8$ & $1: 16$ & $1: 32$ & $1: 64$ & $\begin{array}{c}\text { Serum control } \\
\text { No antigen }\end{array}$ \\
\hline $\begin{array}{l}1 \\
2 \\
3 \\
4\end{array}$ & $\begin{array}{c}++++ \\
++ \\
++++ \\
++++\end{array}$ & $\begin{array}{c}t+ \\
+ \\
+t+ \\
+t\end{array}$ & $\begin{array}{c}++ \\
+ \\
++ \\
++\end{array}$ & $\begin{array}{l}\frac{+}{+} \\
+ \\
+\end{array}$ & $\begin{array}{l}- \\
\bar{t} \\
+\end{array}$ & $\begin{array}{l}- \\
\bar{t}\end{array}$ & $\frac{-}{ \pm}$ & $\begin{array}{l}- \\
- \\
-\end{array}$ \\
\hline
\end{tabular}

* The amount of precipitate is recorded as + to ++++ .

endotoxin according to Schedule I; a second group was made tolerant according to Schedule II; and one group was untreated.

Schedule I (nine rabbits) : $0.025 \mathrm{mg}$. intraperitoneally on Days 1 and 3; $0.05 \mathrm{mg}$. intraperitoneally on Day 5; $0.05 \mathrm{mg}$. intravenously thereafter beginning on Day 9 and continuing at regular intervals until Day 41 for a total of 17 intravenous injections.

Schedule II (ten rabbits) : $0.0005 \mathrm{mg}$. on Days 1, 2 and 4 intravenously. Then $0.001 \mathrm{mg}$. intravenously beginning on Day 10 and continued at regular intervals until Day 58 when a total of 17 intravenous injections was given.

In both Groups I and II, the existence of tolerance to the injection of endotoxin was demonstrated by the characteristically reduced febrile response, and the better physical condition of each animal when compared to non- tolerant ones. The fever indices before and after development of tolerance are shown in Table IV.

On the day of the experiment, each of 21 normal rabbits and 19 tolerant rabbits received $0.1 \mathrm{mg}$. of $E$. coli endotoxin labeled with $\mathrm{Cr}^{\mathrm{b1}} \mathrm{Cl}_{8}$ and possessing radioactivity in the range of 5,440 to 7,000 counts per second per mg. (7). Animals were sacrificed immediately and at various intervals after injection of endotoxin by cardiac puncture and exsanguination.

Mice were divided into two groups. One group served as controls and the other was made tolerant by the intraperitoneal injection of endotoxin according to the schedule described above for mice receiving lethal doses.

The $\mathrm{LD}_{\mathrm{b} 0}$ of tolerant mice on the day of the distribution study was $0.23 \mathrm{mg}$. endotoxin and that of the normal controls was $0.03 \mathrm{mg}$. endotoxin. The tolerant mice were then eight times more resistant than normals to the

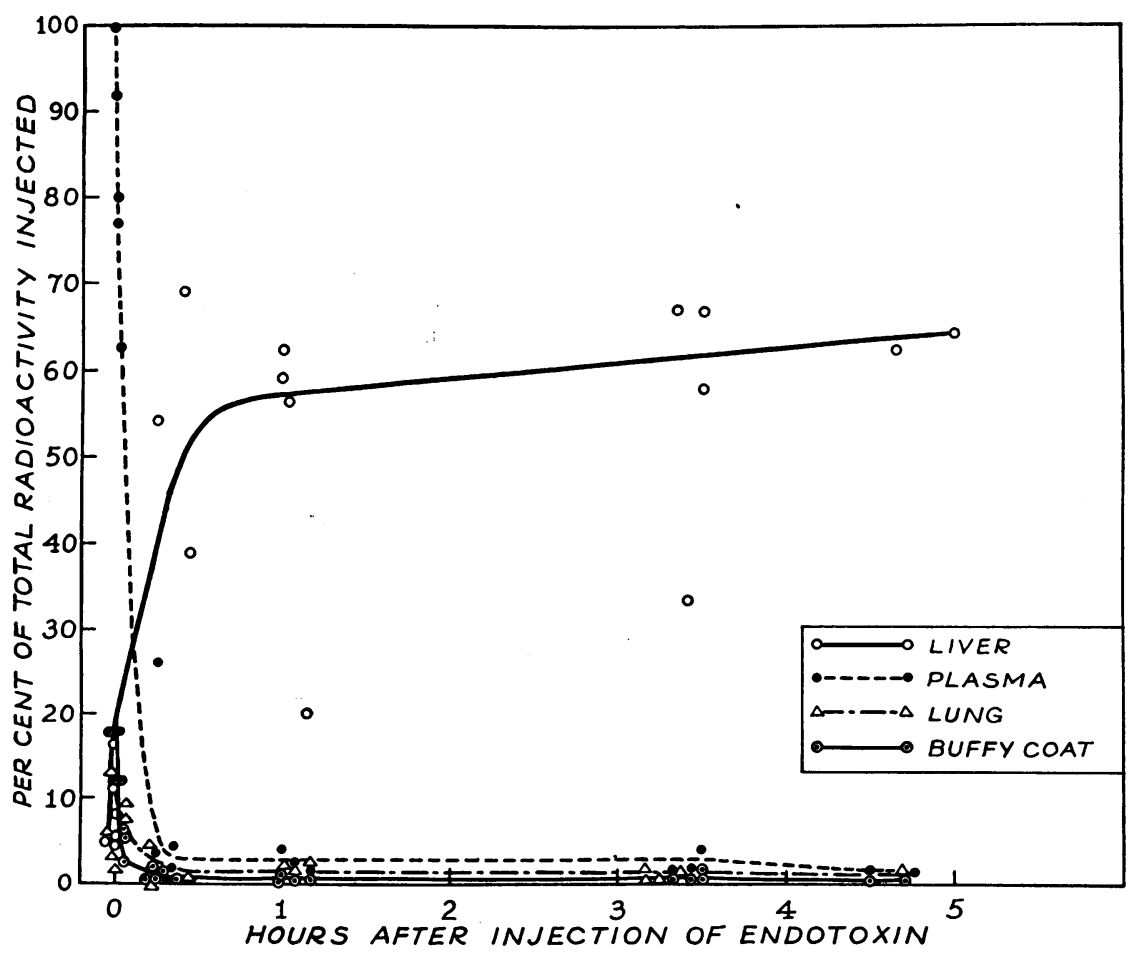

Fig. 15A. Distribution of Radioactivity After Injection of Sublethal Doses of Endotoxin in Twenty-One Normal RabBIts

Each rabbit received $0.1 \mathrm{mg}$. E. coli endotoxin labeled with $\mathrm{Cr}^{\mathrm{s1}} \mathrm{Cl}_{3}$. 


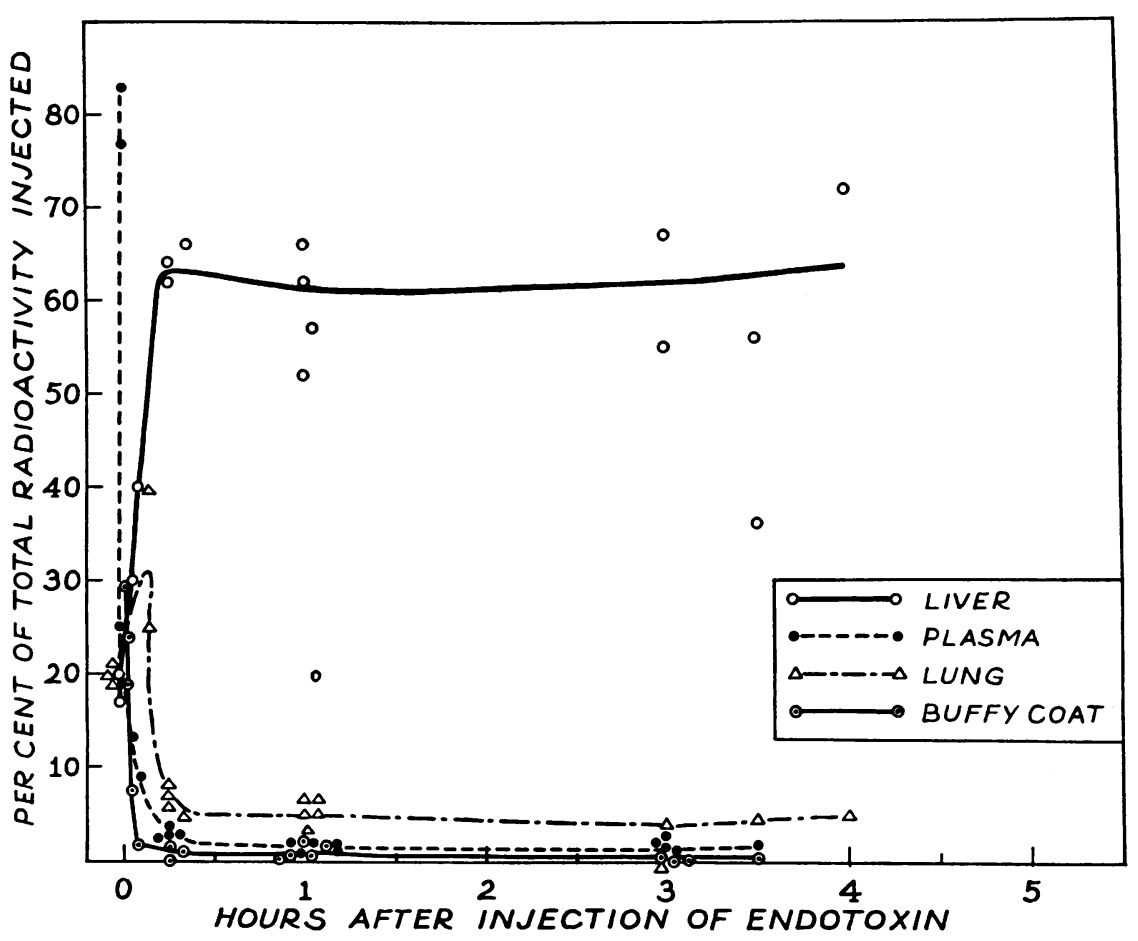

Fig. 15B. Distribution of Radioactivity After Injection of Sublethal Doses of Endotoxin in Nineteen Tolerant Rabits

Each rabbit received $0.1 \mathrm{mg}$. E. coli endotoxin labeled with $\mathrm{Cr}^{51} \mathrm{Cl}_{3}$.

lethal effect of endotoxin. Cardiac blood was obtained in four mice from the group made tolerant and serum precipitin titers were determined as described in capillary tubes. Equal amounts of serum and endotoxin were drawn into the tubes which were then incubated at $37^{\circ} \mathrm{C}$. for three hours. The results are shown in Table V. Each animal was given intravenously $0.01 \mathrm{mg}$. of endotoxin labeled with $\mathrm{Na}_{2} \mathrm{Cr}^{51} \mathrm{O}_{4}$ and sacrificed at the various in-

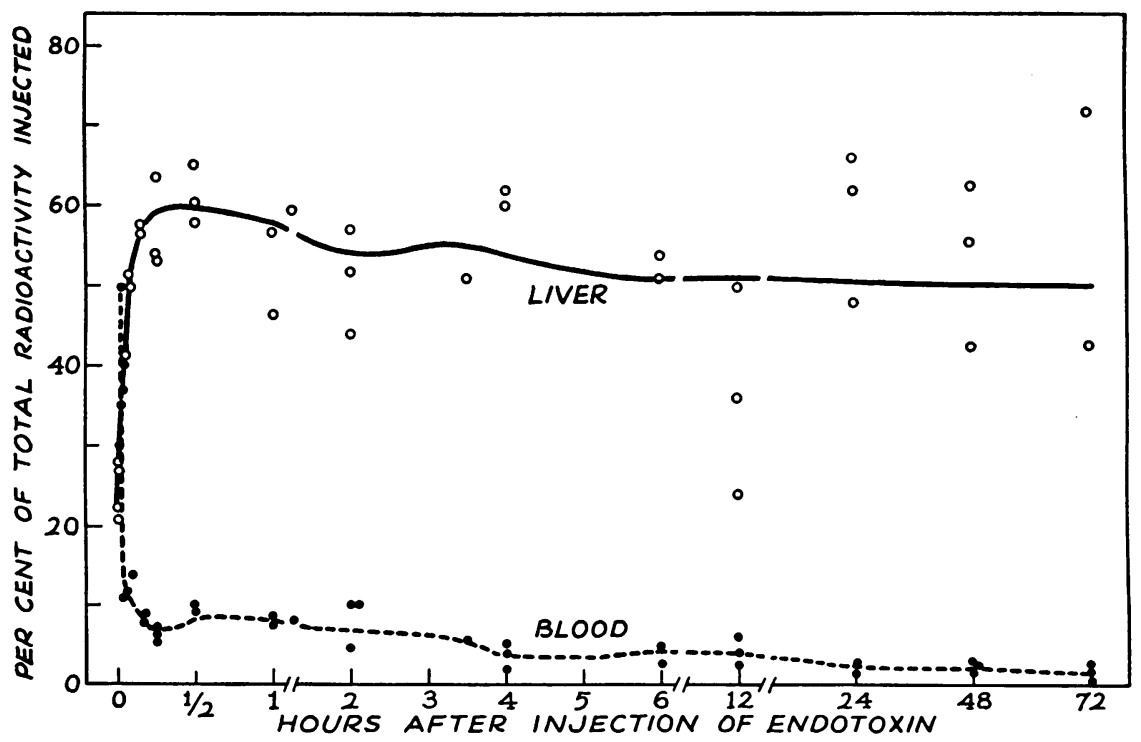

Fig. 16A. Distribution of Radioactivity After Injection of Sublethal Doses in Nontolerant Mice

Each animal received intravenously $0.01 \mathrm{mg}$. E. coli endotoxin labeled with $\mathrm{Na}_{2} \mathrm{Cr}^{51} \mathrm{O}_{4}$. 


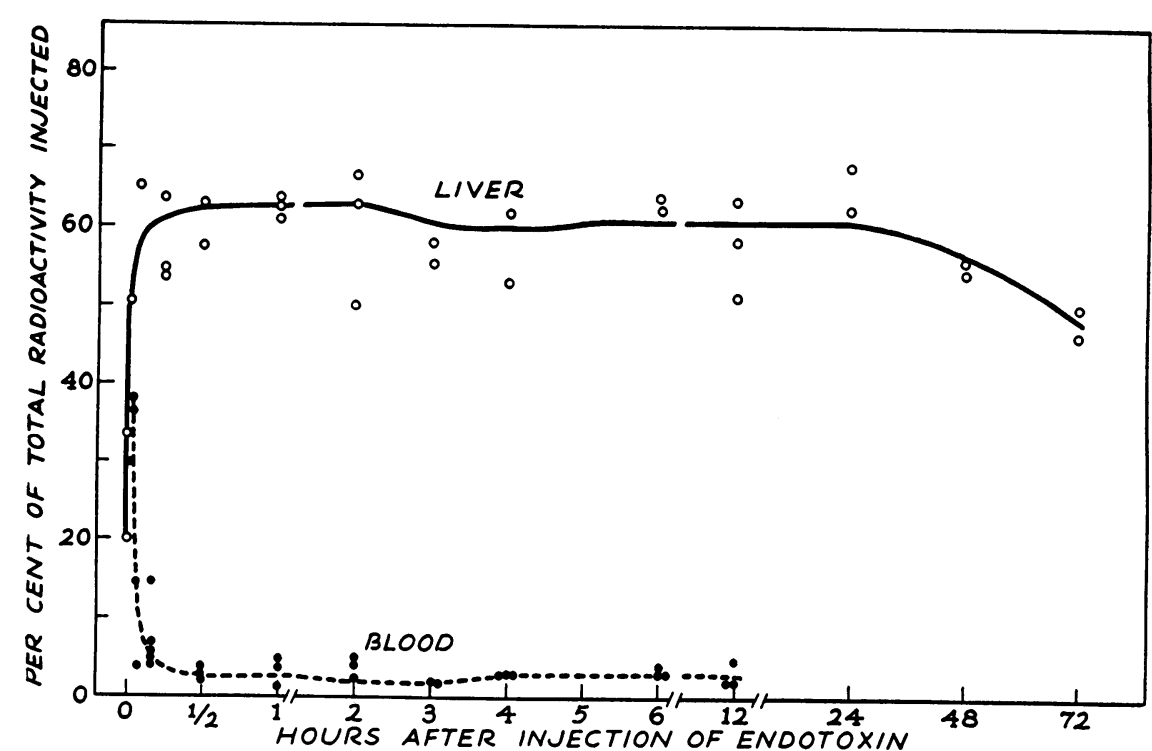

Fig. 16B. Distribution of Radioactivity After Injection of Sublethal Doses in Tolerant Mice

Each animal received intravenously $0.01 \mathrm{mg}$. E. coli endotoxin labeled with $\mathrm{Na}_{2} \mathrm{Cr}^{51} \mathrm{O}_{4}$.

tervals designated in Figure 16A and 16B. Each mg. of injected radioactive endotoxin produced 1,270 counts per second in the scintillation counter.

s's

RESULTS

The distribution curves in both rabbits and mice given sublethal doses are very similar and can be described together because they elucidate the same four points. The results for rabbits are given in Figures 15A and 15B; those for mice in Figures 16A and 16B. Because no differences were encountered between the two groups of tolerant rabbits, the results are plotted together on the same figure. They disclose that:

1. In both tolerant and nontolerant animals, regardless of species, there was a massive removal of endotoxin into the liver in amounts equal approximately to 60 per cent or more within 15 minutes. Associated with this was a rapid removal of endotoxin from the blood so that during the same period of time the concentration in the circulation had fallen below 10 per cent.

2. The great differences between tolerant and nontolerant animals observed with the use of massive doses ( 60 to 150 times greater than those used here) were not found. It was possible, however, to detect slight but consistent differences in the two groups. In tolerant mice, blood concentration fell below 5 per cent within 15 minutes and remained there, while in nontolerant mice the blood concentration remained between 5 and 10 per cent for four hours. Distribution curves for the liver also suggested that slightly higher percentages of endotoxin appear there in tolerant animals (both rabbits and mice) than in nontolerant animals.

3. A heavy distribution of endotoxin in the buffy coat was observed in both normal and tolerant rabbits immediately after injection. Concentrations as high as 17.7 per cent were present in the buffy coat of normal rabbits and of 29.4 per cent in that of tolerant rabbits. After the first few minutes, however, as the polymorphonuclear leukocytes disappeared from the blood (Figure 17), these cells seemingly removed their endotoxin with them from the circulation and only small amounts were found in the buffy coat thereafter.

4. Among the remaining tissues, only the lung and spleen of rabbits exhibited significant concentrations of endotoxin. A slightly greater uptake was observed in the lungs of tolerant rabbits than nontolerant rabbits during the first 15 minutes. This could not be related to the presence of circulating precipitins, however, because these were absent in the group of tolerant rabbits used here. In mice, even though precipitins were demonstrated, the titer was apparently too low to 
effect pulmonary localization with these small amounts of endotoxin.

The uptake by the spleen in mice was barely detectable. In rabbits, however, the concentrations varied from 0.5 to 3 per cent of the total endotoxin injected. Based on the relative weight of the spleen, this represents a concentration of 20 to 80 times. No important differences were discerned between the uptake by spleens from normal and tolerant animals.

Only traces of endotoxin, if any, were found in the urine or intestinal contents so that removal from the blood could be accounted for almost entirely by localization in the reticuloendothelial system in the liver.

\section{DISCUSSION}

Susceptibility to the lethal action of endotoxin in mice and to its pyrogenic effect in rabbits seemed directly related to the speed and permanence with which massive doses of endotoxin disappeared from the blood. All tolerant animals removed massive doses of endotoxin from the blood in much less time than did normal animals. Unless such massive amounts of endotoxin were injected, however, this capacity for accelerated removal in tolerant animals was not apparent; instead both normal and tolerant animals rapidly cleared sublethal doses of endotoxin from the circulation at approximately equal rates. The following discussion of the altered distribution in tolerant animals is therefore concerned only with the results obtained with massive doses.

Upon the swift removal of massive doses from the blood of tolerant mice, endotoxin passed into the liver and sometimes the lung. The uptake by the lung in rabbits and mice depended on the serum antibody titer. With precipitin titers in the average range of $1: 8$ or higher, high pulmonary localization occurred after injection of massive doses; with titers of $1: 2$ or less, it never occurred. The high pulmonary uptake and the high antibody titer were not essential, however, for tolerance or speedy removal. Thus, tolerance was induced and antibody formation suppressed in mice given irradiation just before the start of injections for producing tolerance; and nonirradiated mice and rabbits developed tolerance after the usual schedule of injections without always forming high titers of circulating antibody. In these two groups of tolerant mice (irradiated tolerant and normal tolerant with low precipitins), endotoxin was removed from the blood more rapidly than normally but not as fast as in those mice with antibody titers of $1: 8$ or higher.

Although antibody thus contributes to the swift

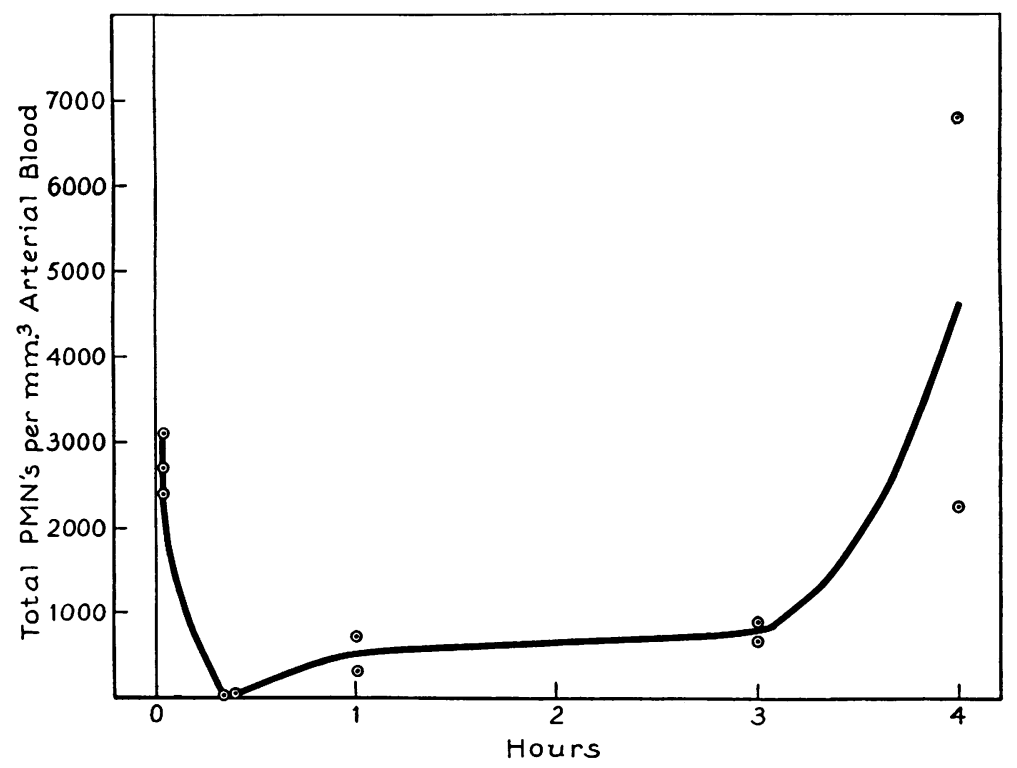

Fig. 17. Polymorphonuclear Leukocyte (PMN) Counts in Nontolerant Rabbits Receiving 0.1 Mg. E. coli Endotoxin Labeled With $\mathrm{CR}^{\mathrm{II}} \mathrm{Cl}_{3}$ 
removal into the lung, high titers of antibody cannot by themselves provide protection in mice. A demonstration of this was observed in mice whose tolerance disappeared despite the persistence of circulating antibody at a titer of $1: 16$ or above. In these animals circulating endotoxin rapidly disappeared into the lung; . after two hours, however, pulmonary concentrations fell almost to zero and circulating endotoxin reappeared in high concentrations. It would appear, therefore, that circulating antibody may contribute to tolerance in mice by inducing rapid but temporary pulmonary removal of endotoxin. Tolerance only became evident, however, when endotoxin from the lung localized in the liver at a rate which kept the circulating level from rising. Removal of endotoxin by the liver in tolerant mice was probably the principal factor responsible for maintaining a low circulating level of endotoxin. The low pulmonary uptake in tolerant animals lacking high titers of precipitins was compensated for by a high rapid initial uptake by the liver. Unlike mice, the pulmonary localization of endotoxin in high concentration persisted in tolerant rabbits with high titers of precipitins. It is possible, therefore, that in rabbits the presence of antibody provides a less transient protective action.

The relationship between precipitin titer and the immediate pulmonary localization after intravenous injection of lethal doses suggests that precipitins combine instantly with endotoxin as it enters the circulation and thereby forms precipitates which are filtered out by the pulmonary capillaries. Precipitins could also alter the surface of endotoxin particles and render them more suitable for ingestion by the numerous and actively phagocytic pulmonary macrophages (septal cells of Maximow and Bloom [14]). The speed with which endotoxin leaves the lung in mice makes the process of precipitation without phagocytosis appear to be a more likely possibility. Pulmonary levels may drop from 50 to 60 per cent to 3 per cent in one hour. Because it is unlikely that phagocytosed particles could leave the cells and reappear so rapidly in the blood, it is suggested that the pulmonary capillaries trap the endotoxin-antibody precipitates in mice and later capillary dilation enables them to be washed out into the general circulation where they can break up into smaller particles. In rabbits, on the other hand, the per- sistence of radioactivity in the lung favors the possibility that the pulmonary macrophages may ingest precipitated particles.

The tolerance which occurs in the absence of circulating antibody is accompanied by a marked increase in hepatic localization of endotoxin after injection of lethal doses. This would suggest that the Kupffer cells become more active individually in removing massive lethal doses of endotoxin, and that their ability to do so may represent a cellular immunity characterized by an increased resistance of the individual reticuloendothelial cells to the damaging action of the endotoxin. That such damage occurs is indicated by: 1) the work of Biozzi, Benacerraf, and Halpern (15) who found that the endotoxin of Salmonella typhosa suppressed the ability of hepatic reticuloendothelial cells to ingest carbon particles; and 2) the observation that the first dose of endotoxin given to prepare rabbits for the Shwartzman reaction cut in half the ability of the liver to remove a second dose of endotoxin injected into the circulation during the provocative stage (16).

Another possibility is that tolerance leads to a proliferation of Kupffer cells so that their increased number can then cope with larger quantities of circulating endotoxin. Either mechanism would hardly be consistent, however, with the failure of the colloidal iron used in these experiments to block hepatic uptake in mice and reduce their tolerance. While it is likely that the dosage of colloidal iron and other experimental conditions may account for these negative results, they raise the possibility that the increased hepatic localization of radioactivity may be related to other factors than the altered activity of reticuloendothelial cells. It is conceivable, for example, that tolerant animals differ from nontolerant animals in their ability to resist the profound alterations in splanchnic blood flow which influence the hepatic circulation (17).

\section{SUMMARY}

Although normal and tolerant animals both cleared sublethal doses of endotoxin rapidly and at approximately equal rates, a great difference was observed between tolerant and nontolerant animals in the hepatic localization and plasma clearance of massive doses of endotoxin. In tol- 
erant animals massive doses of radioactive endotoxin were removed much more rapidly from the circulating blood and more of it was deposited in the liver and leukocytes than in the nontolerant animal. If circulating antibody (precipitin) was present in high titer, the endotoxin was removed from the circulation still more rapidly because of an enormous and instantaneous deposition in the lung. In mice this pulmonary deposition was only transient; but in rabbits the high pulmonary localization lasted for several hours.

These results indicate that tolerance to lethal doses of endotoxin depends on speedy and permanent removal of circulating endotoxin into hepatic and other cells. Although not essential for tolerance, circulating antibody may contribute to it by inducing rapid but temporary pulmonary removal which by itself cannot provide protection.

\section{REFERENCES}

1. Morgan, H. R. Tolerance to the toxic action of somatic antigens of enteric bacteria. J. Immunol. 1948, 59, 129.

2. Morgan, H. R. Resistance to the action of the endotoxins of enteric bacilli in man. $\mathrm{J}$. clin. Invest. 1948, 27, 706.

3. Beeson, P. B. Tolerance to bacterial pyrogens. I. Factors influencing its development. J. exp. Med. 1947, 86, 29.

4. Beeson, P. B. Development of tolerance to typhoid bacterial pyrogen and its abolition by reticuloendothelial blockade. Proc. Soc. exp. Biol. (N. Y.) 1946, 61, 248.

5. Beeson, P. B. Effect of reticulo-endothelial blockade on immunity to Shwartzman phenomenon. Proc. Soc. exp. Biol. (N. Y.) 1947, 64, 146.

6. Braude, A. I., Carey, F. J., and Zalesky, M. Studies with radioactive endotoxin. II. Correlation of physiologic effects with distribution of radioactivity in rabbits injected with lethal doses of $E$. coli endo- toxin labelled with radioactive sodium chromate. J. clin. Invest. 1955, 34, 858.

7. Braude, A. I., Carey, F. J., Sutherland, D., and Zalesky, M. Studies with radioactive endotoxin. I. The use of $\mathrm{Cr}^{51}$ to label endotoxin of Escherichia coli. J. clin. Invest. 1955, 34, 850.

8. Reed, L. J., and Muench, H. A simple method of estimating fifty percent endpoints. Amer. J. Hyg. 1938, 27, 493.

9. Courtice, F. C., and Gunton, R. W. The determination of blood volume by the carbon monoxide and dye (T-1824) methods in rabbits. J. Physiol. (Lond.) 1949, 108, 405.

10. Kaplan, H. M. The rabbit in experimental physiology. New York, Scholar's Library, 1956.

11. Armin, J., Grant, R. T., Pels, H., and Reeve, E. B. The plasma, cell, and blood volumes of albino rabbits as estimated by the dye (T-1824) and "P marked cell methods. J. Physiol. (Lond.) 1952, $116,59$.

12. Berlin, N. I., Huff, R. L., Van Dyke, D. C., and Hennessy, T. G. The blood volume of the adult rat, as determined with $\mathrm{Fe}^{\mathrm{so}}$ and $\mathrm{P}^{22}$ labelled red cells. Proc. Soc. exp. Biol. (N. Y.) 1949, 71, 176.

13. Smith, R. T., Lewis, T., and Good, R. A. Generalized Shwartzman reaction. V. Intravenous injection of colloidal iron or carbon on response of rabbits to meningococcal toxin. Proc. Soc. exp. Biol. (N. Y.) $1953,82,712$.

14. Maximow, A. A., and Bloom, W. A Textbook of Histology. Philadelphia, W. B. Saunders Co., 1930.

15. Biozzi, G., Benacerraf, B., and Halpern, B. N. The effect of Salm. typhi and its endotoxin on the phagocytic activity of the reticulo-endothelial system in mice. Brit. J. exp. Path. 1955, 36, 226.

16. Smith, R. T., Braude, A. I., and Carey, F. J. The distribution of $\mathrm{Cr}^{51}$ labeled $E$. coli endotoxin in the generalized Shwartzman reaction. J. clin. Invest. 1957, 36, 695.

17. Weil, M. H., MacLean, L. D., Visscher, M. B., and Spink, W. W. Studies on the circulatory changes in the dog produced by endotoxin from gram-negative microorganisms. J. clin. Invest. 1956, 35, 1191. 